\title{
Molecular identification and histological aspects of Renicola sloanei (Digenea: Renicolidae) in Puffinus puffinus (Procellariiformes): a first record
}

Identificação molecular e aspectos histológicos de Renicola sloanei (Digenea: Renicolidae) em Puffinus puffinus (Procellariiformes): primeiros registros

Andressa Maria Rorato Nascimento de Matos ${ }^{1,2}$; Fernanda Louise Pereira Lavorente ${ }^{2,3}$; Elis Lorenzetti ${ }^{3}$; Mário Roberto Castro Meira Filho ${ }^{4}$; Daniela Farias da Nóbrega ${ }^{4}$; Andreas Lazaros Chryssafidis ${ }^{5}$; Admilton Gonçalves de Oliveira ${ }^{6}$; Camila Domit ${ }^{4}$; Ana Paula Frederico Rodrigues Loureiro Bracarense ${ }^{1,2 *}$

\footnotetext{
${ }^{1}$ Laboratório de Patologia Animal, Departamento de Medicina Veterinária Preventiva, Universidade Estadual de Londrina - UEL, Londrina, PR, Brasil

${ }^{2}$ Programa de Pós-graduação em Ciência Animal, Centro de Ciências Agrárias, Universidade Estadual de Londrina - UEL, Londrina, PR, Brasil

${ }^{3}$ Laboratório de Virologia Animal, Departamento de Medicina Veterinária Preventiva, Universidade Estadual de Londrina - UEL, Londrina, PR, Brasil

${ }^{4}$ Laboratório de Ecologia e Conservaçăo, Centro de Estudos do Mar, Universidade Federal do Paraná - UFPR, Pontal do Paraná, PR, Brasil

${ }^{5}$ Laboratório de Parasitologia Veterinária, Departamento de Medicina Veterinária Preventiva, Universidade Estadual de Londrina UEL, Londrina, PR, Brasil

${ }^{6}$ Laboratório de Microscopia Eletrônica e Microanálises, Departamento de Biologia Geral, Universidade Estadual de Londrina UEL, Londrina, PR, Brasil
}

Received February 1, 2019

Accepted April 8, 2019

\begin{abstract}
Renicolids are parasites that inhabit the renal tubules and ureters of molluscivorous and piscivorous birds. Puffinus puffinus is a migratory seabird that was identified as the definitive host of Renicola spp. Studies focusing on the renicolid species and the resulting renal lesions are valuable for their association with causes of stranding in seabirds. The aim of this study was to identify the renicolid trematodes and evaluate the histological findings in two $P$. puffinus stranded on the coast of Paraná state, Brazil. The parasites were evaluated by histologic, ultrastructural and molecular assays, while tissue changes were analyzed by histologic methods. The morphological and morphometrical characteristics of the parasites, along with polymerase chain reaction and sequencing assays (ribosomal and mitochondrial regions), identified the species as Renicola sloanei. The results also suggest that this helminth can be the adult form of Cercaria pythionike. The dilation of collecting ducts was the main histological finding in the kidneys. In conclusion, $R$. sloanei was identified, and for the first time, $P$. puffinus was described as a host of this digenean inducing mild renal changes.
\end{abstract}

Keywords: Histopathological, kidney, manx shearwater, renicolid, seabirds, trematodes.

\section{Resumo}

Renicolídeos são parasitos que habitam túbulos renais e ureteres de aves que se alimentam de moluscos e peixes. Puffinus puffinus, ave marinha migratória, foi registrada como hospedeiro definitivo de Renicola spp. Estudos relacionados com as espécies de renicolídeos e as lesóes renais resultantes são importantes para o entendimento das causas de óbito de aves marinhas. O objetivo deste estudo foi identificar os trematódeos renicolídeos e avaliar os achados histológicos em dois P. puffinus encalhados no litoral do Estado do Paraná, Brasil. Os parasitos foram avaliados por ensaios histológicos, ultraestruturais e moleculares, enquanto as alteraçóes teciduais foram analisadas por métodos histológicos. As características morfológicas e morfométricas dos parasitos, juntamente com a reação em cadeia da polimerase e sequenciamento (regiốes ribossomal e mitocondrial), identificaram a espécie como Renicola sloanei. Os resultados também sugerem que este helminto pode ser a forma adulta de Cercaria pythionike. A dilatação dos ductos coletores foi o principal achado histológico renal. Em conclusão, $R$. sloanei foi identificado, e pela primeira vez P. puffinus foi descrito como hospedeiro deste digenético induzindo alteraçóes renais discretas.

Palavras-chave: Histopatologia, rim, bobo-pequeno, renicolídeo, aves marinhas, trematódeo.

\footnotetext{
*Corresponding author: Ana Paula Frederico Rodrigues Loureiro Bracarense. 


\section{Introduction}

Puffinuspuffinus (Brünnich, 1764), a procellariiform popularly known as the Manx shearwater, remains in Europe during the breeding season and then migrates to the South Atlantic between September and February for feeding. The entire Brazilian coast is a feeding ground for P. puffinus (SICK, 1997). The first description of a parasitic renal infection in this bird was in 1956 when two renicolid trematodes were morphologically identified, with differences only in the extent of the vitelline glands (WRIGHT, 1956).

Digeneans of the Renicola Cohn, 1904 genus, which includes approximately 28 species, inhabit the renal tubules and ureters of birds that eat bivalves and fish (WRIGHT, 1954a; GIBSON, 2008; WORMS, 2018). The infection by this genus was previously described in P. puffinus, where the large number of worms induced the dilation of some renal tubules and ducts and occluded others due to the increased pressure (WRIGHT, 1956). In the same study, morphological similarities were identified between Renicola sp. in these birds and Renicola sloanei Wright, 1954 (identified in other species of marine birds) including a suggested association between this adult parasite and the Cercaria pythionike metacercariae (WRIGHT, 1956). In addition, R. sloanei was also reported in Uria aalge (COLE, 1959).

In Brazil, there are previous descriptions of Renicola sp. from Sterna spp., Larus dominicanus Lichtenstein, 1823 and Sula leucogaster (Boddaert, 1783) belonging to the Instituto Oswaldo Cruz collection (WRIGHT, 1954b). More recently, Renicola sp. was reported in Spheniscus magellanicus (Foster, 1781) (JERDY et al., 2016).

Parasitic fauna studies can provide information about the distribution, feeding habits and population stocks of both intermediate and definitive hosts, however, data about the complex biology and ecology still insufficient in this context (MACKENZIE et al., 2008). In a first study in the Brazilian Northeast region including P. puffinus, various ectoparasites and endoparasites species were identified (MELO et al., 2012); however, renal digeneans were not described. Considering these aspects, the aim of this study was to identify the renicolid trematodes in P. puffinus using morphological and molecular assays and to evaluate the renal histological lesions.

\section{Materials and Methods}

\section{Hosts}

Two P. puffinus found dead in December 2017, stranded in the Paraná state $\left(25^{\circ} 44^{\prime} \mathrm{S}\right.$ and $\left.48^{\circ} 29^{\prime} \mathrm{W}\right)$, southern Brazil, were submitted to necropsy as part of the ongoing monitoring of the stranding program as part of the Santos Basin Beach Monitoring Project (PMP-BS). The collet of two animals was granted by the Brazilian Institute of Environment and Renewable Natural Resources - Ministry of Environment (no 640/2015).

\section{Histological analysis of kidneys}

Kidney samples were fixed in $10 \%$ buffered formalin solution, dehydrated in increasing alcohols and embedded in paraffin. Sections of $4 \mu \mathrm{m}$ were stained with hematoxylin and eosin for histologic analysis.

\section{Histological preparation of helminths}

The worms were fixed in AFA (a solution of ethanol, formaldehyde and acetic acid), stained with Mayer's carmalum (MC) and Delafield's hematoxylin (DH) and mounted on histological slides with Entellan (Merck, Germany) (AMATO \& AMATO, 2010).

The voucher specimens on permanent slides were then deposited in the Helminthological Collection of the Oswaldo Cruz Institute (CHIOC numbers 39034 and 39035), Rio de Janeiro, Brazil.

\section{Measures of helminths}

All measurements were done based on Wright (1954b, 1956) using an Opticam Microscopy Technology 0500R (Doral, FL, USA) image analysis system.

The following parameters were measured: body (length and width; the maximum body width and the width in the ventral sucker level), oral sucker (length and width), pharynx (length and width), ventral sucker (length and width), and the spines in the medium lateral level of the body (length). For the evaluation of the eggs (length and width), 10 mature eggs (with a brown-shell and containing a miracidium) per renicolid were selected. To assess the extension of the vitelline glands and the caeca, the body length was divided into five equal parts.

A descriptive statistical analysis was conducted to calculate the mean, standard deviation (SD), maximum and minimum values for each character, and the length/width ratios for the suckers and the body.

\section{Ultrastructural assessment}

The digenean parasites sampled from P.puffinus were submitted to scanning electron microscopy (SEM). The parasites were fixed in $2.5 \%$ glutaraldehyde in $0.1 \mathrm{M}$ sodium cacodylate buffer ( $\mathrm{pH} 7.2)$ at room temperature for $24 \mathrm{~h}$. The specimens were then washed with sodium cacodylate buffer $(0.1 \mathrm{M}, \mathrm{pH} 7.2)$ and treated with $1 \%$ osmium tetroxide in sodium cacodylate buffer $(0.1 \mathrm{M}$, $\mathrm{pH} 7.2)$ for $1 \mathrm{~h}$ before being gradually dehydrated in ethanol (70, 80, 90 and 100\%) and dried to the critical point (Critical Point Dryer CPD 030, Bal-Tec Union Ltd., Liechtenstein). The dried parasites were coated with gold (Sputter Coater SDC 050, Bal-Tec Union Ltd., Liechtenstein) and analyzed using a scanning electron microscope (FEI Quanta 200, Eindhoven, Netherlands/Holland).

\section{DNA extraction, PCR, and sequencing}

Trematodes were removed from the kidneys and the DNA extraction was carried out using a commercial kit (DNeasy Blood and Tissue $^{\text {TM }}$ kit, QIAGEN $^{\ominus}$, Valencia, CA). The Table 1 shows the primers, the annealing temperatures, and the references of each 
Table 1. Sequence, annealing temperature (AT) and reference of primers used to perform the amplification and sequencing of nuclear (ITS2) and mitochondrial (ND1, CO1) DNA loci of the renicolids from Puffinus puffinus on the coast of Paraná state, Brazil.

\begin{tabular}{|c|c|c|c|c|}
\hline Locus & Primer & Sequence (5'-3') & AT & Reference \\
\hline \multirow{2}{*}{ ITS2 } & SPIR 1 & GAGGGTCGGCTTATTATCTATCA & $50^{\circ} \mathrm{C}$ & Stacy et al. (2010) \\
\hline & SPIR 2 & TCACATCTGATCCGAGGTCA & & \\
\hline \multirow[t]{2}{*}{ ND1 } & ND1J & AGATTCGTAAGGGGCCTAATA & $43^{\circ} \mathrm{C}$ & Bray et al. (1999) \\
\hline & ND1J2A & CTTCAGCCTCAGCATAATC & & Morgan \& Blair (1998) \\
\hline \multirow[t]{3}{*}{$\mathrm{CO} 1$} & JB3 & TTTTTTGGGCATCCTGAGGTTTAT & $48^{\circ} \mathrm{C}$ & Bowles et al. (1992) \\
\hline & JB4-5 & TAAAGAAAGAACATAATGAAAATG & & \\
\hline & CO1-R-Trema & CAACAAATCATGATGCAAAAGG & $50{ }^{\circ} \mathrm{C}$ & Miura et al. (2005) \\
\hline
\end{tabular}

primer used to perform the amplification of the ITS2 (internal transcribed spacer 2), ND1 (nicotinamide adenine dinucleotide dehydrogenase, subunit 1), and CO1 (cytochrome C oxidase, subunit 1) regions.

The PCR amplicons were detected by electrophoresis on $2 \%$ agarose gel in a TBE buffer $(89 \mathrm{mM}$ Tris, $89 \mathrm{mM}$ boric acid, 2 mM EDTA) containing ethidium bromide $(0.5 \mu \mathrm{g} / \mathrm{mL})$ and visualized under UV light. The PCR amplicons were purified using the illustra GFX PCR DNA and Gel Band Purification Kit (GE Healthcare, Little Chalfont, Buckinghamshire, UK) and quantified using a Qubit ${ }^{\circledR}$ Fluorometer (Invitrogen Life Technologies, Eugene, OR, USA). The PCR amplicons were then sequenced using a BigDye ${ }^{\otimes}$ Terminator v3.1 Cycle Sequencing Kit (Applied Biosystems, Foster City, CA, USA) in an ABI3500 Genetic Analyzer sequencer (Applied Biosystems, Foster City, CA, USA) with the same forward and reverse primers used in the initial PCR assay.

The sequence quality analyses were performed using PHRED and the sequences were accepted if the base quality was $\geq 20$. The consensus sequences were determined using the CAP3 software (EMBRAPA, 2019). The nucleotide (nt) sequences were compared to the sequences deposited in GenBank using BLAST software (NCBI, 2019). Pairwise and multiple sequence alignments at the nt level were realized with ClustalW in MEGA (version 7.0.26) (Supplementary Material - Tables S1, S2, and S3).

The phylogenetic trees based on the nt sequences were built using the Maximum-Likelihood method with a Kimura two-parameter model + invariant sites $(\mathrm{K} 2+\mathrm{I})$ to ITS2 and Hasegawa-Kishino-Yano model + gama distribution $(\mathrm{HKY}+\mathrm{G})$ to ND1 and CO1 loci, according to find best DNA model (Supplementary Material Tables S4, S5, and S6) in MEGA (version 7.0.26) (KUMAR et al., 2016). Bootstrapping was statistically supported with 1,000 replicates. The nt sequence identity matrices were generated by BioEdit software version 7.2.6.1.

The sequences obtained in this study were deposited in the GenBank database (accession numbers: MH021181, MH021182, MK463857, and MK463858).

\section{Results}

\section{Gross and histologic findings of the kidneys}

Macroscopically, the kidneys of $P$. puffinus had small black multifocal areas where worms were found in pairs inside of cyst-like structures within the renal tissue and distributed in the whole

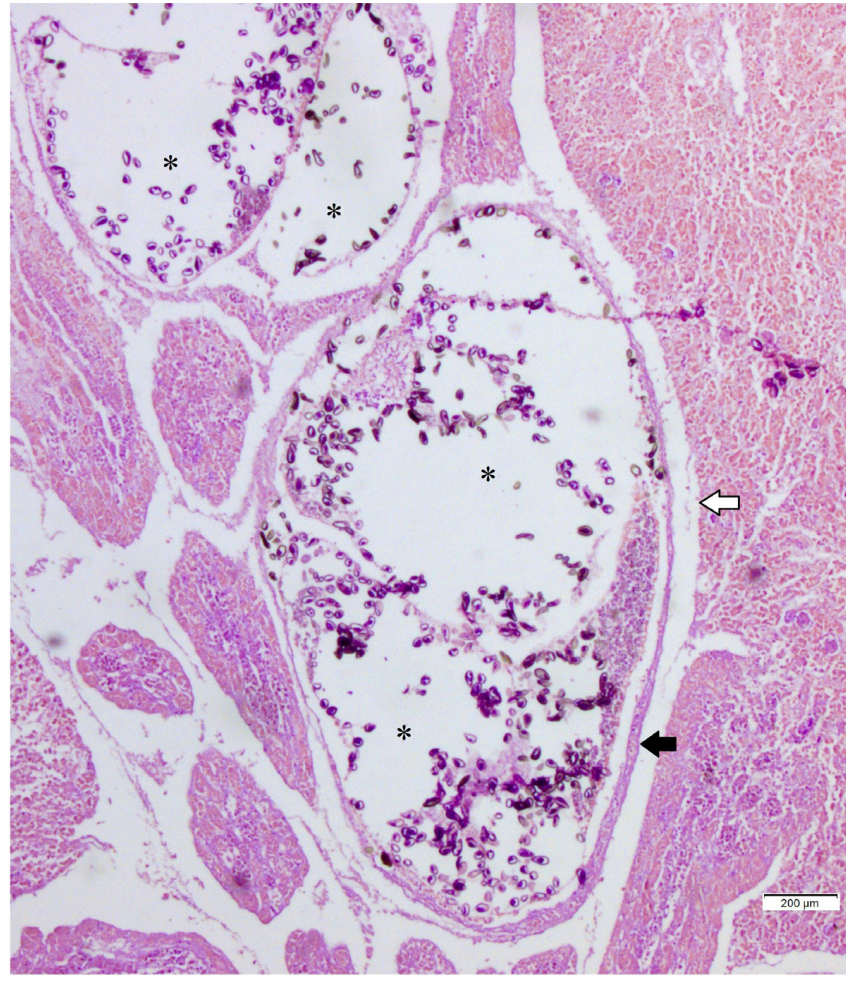

Figure 1. Kidney of Puffinus puffinus from the coast of Paraná state, Brazil. Ectasia ductal in kidney with Renicola sloanei $\left({ }^{*}\right)$ filled with eggs. White arrow - renal duct edge. Black arrow - cystic formation around the parasites (HE, Bar $200 \mu \mathrm{m})$.

organ. Microscopic findings were characterized by the dilation of the collecting ducts associated with the intraluminal accumulation paired renicolids in dilated ducts (Figure 1).

\section{Histologic and ultrastructural analysis of the parasites}

The morphometry analyses were executed in 99 helminths (Table 2). In mature specimens filled with eggs, few parameters were measured, such as the body length and the dimensions of the oral sucker and eggs.

Most worms presented a roughly oval body with a blunt anterior extremity that gradually tapered toward the other end; there was a large variation in length (Figure 2A). The cuticle had numerous little spines (Figures $2 \mathrm{C}$ and $2 \mathrm{~F}$ ), and the oral sucker 
Table 2. Measurements ( $\mu \mathrm{m})$ of adult renicolids from seabirds with similar distribution as the Puffinus puffinus.

\begin{tabular}{|c|c|c|c|c|c|c|c|c|}
\hline Renicolidae & & Renicola sloanei & $\begin{array}{c}\text { Renicola } \\
\text { sloanei }\end{array}$ & $\begin{array}{c}\text { Renicola } \\
\text { sp. }\end{array}$ & Renicola sp. & Renicola sp. & & Renicola lari \\
\hline Source & & This study & $\begin{array}{c}\text { Wright } \\
\text { (1954a) }\end{array}$ & $\begin{array}{l}\text { Wright } \\
(1956)\end{array}$ & Jerdy et al. (2016) & $\begin{array}{c}\text { Wright } \\
\text { (1954b) }\end{array}$ & & Heneberg et al. (2016) \\
\hline Host (locality) & & Puffinus puffinus (BR) & $\begin{array}{c}\text { Pygoscelis } \\
\text { antarctica } \\
\text { and Eudyptes } \\
\text { chrysolophus } \\
\text { (UK) }\end{array}$ & $\begin{array}{l}\text { Puffinus } \\
\text { puffinus } \\
\text { (UK) }\end{array}$ & $\begin{array}{c}\text { Spheniscus } \\
\text { magellanicus (BR) }\end{array}$ & $\begin{array}{c}\text { Larus } \\
\text { dominicanus } \\
\text { (BR) }\end{array}$ & & $\begin{array}{l}\text { Chroicocephalus ridibundus } \\
\text { (CR) }\end{array}$ \\
\hline Measurements & $\mathbf{N}$ & Mean \pm SD (Range) & Range & Range & Mean \pm SD (Range) & Mean & $\mathbf{N}$ & Mean \pm SD (Range) \\
\hline B length & 60 & $2063 \pm 449(1287-3096)$ & $1470-2710$ & $940-1950$ & $1162 \pm 82(1073-1254)$ & 2000 & 30 & $1268 \pm 210(1000-1771)$ \\
\hline B width ${ }^{a}$ & 45 & $1039 \pm 279(631-1659)$ & $690-1260$ & $360-980$ & $603 \pm 56(548-695)$ & 1000 & 30 & $794 \pm 130(522-1000)$ \\
\hline B width ${ }^{b}$ & 22 & $935 \pm 258(610-1520)$ & & & & & & \\
\hline OS length & 71 & $278 \pm 74(158-536)$ & $257-329$ & $136-280$ & $132 \pm 9.8(117-142)$ & 240 & 30 & $220 \pm 37(174-296)$ \\
\hline OS width & 72 & $324 \pm 88(115-666)$ & $229-286$ & $120-180$ & $134 \pm 15.5(124-164)$ & $150-180$ & 30 & $266 \pm 36(203-348)$ \\
\hline Pharynx length & 59 & $106 \pm 20(68-158)$ & 114 & $60-96$ & $70 \pm 15.7(53-84)$ & 84 & 30 & $89 \pm 10(70-104)$ \\
\hline Pharynx width & 61 & $122 \pm 22(92-173)$ & 114 & $60-80$ & $50 \pm 10(40-60)$ & 80 & 30 & $79 \pm 10(70-99)$ \\
\hline VS length & 29 & $155 \pm 29(111-270)$ & $114-129$ & $80-144$ & & 105 & 30 & $98 \pm 15(81-145)$ \\
\hline VS width & 31 & $150 \pm 29(115-267)$ & & & & & 30 & $98 \pm 15(81-145)$ \\
\hline Eggs length & 583 & $30 \pm 2(24-35)$ & $28-34$ & $34-38$ & $28.5 \pm 1.6(26-32)$ & $38-42$ & 30 & $47 \pm 1(46-48)$ \\
\hline Eggs width & 583 & $16 \pm 1(12-19)$ & $16-18$ & $19-22$ & $15.3 \pm 1.4(14-18)$ & $17-21$ & 30 & $27 \pm 1(26-28)$ \\
\hline Spines length & 167 & $12 \pm 0.31(8-20)$ & & & & & 30 & $9.5 \pm 1.0(8-10)$ \\
\hline Length:width ${ }^{c}$ & 38 & $2 \pm 0.28(1: 1.6-2.9)$ & & & & & 30 & $1.6 \pm 0.2(1: 1.1-2.0)$ \\
\hline OS:VS length ${ }^{\mathrm{d}}$ & 20 & $1.8 \pm 0.7(1: 0.2-1)$ & & & & & 30 & $2.3 \pm 0.5(1: 1.1-3.4)$ \\
\hline OS:VS width ${ }^{\mathrm{e}}$ & 21 & $2.3 \pm 0.9(1: 0.2-1.5)$ & & & & & 30 & $2.8 \pm 0.5(1: 1.6-4.0)$ \\
\hline
\end{tabular}

${ }^{\mathrm{a}}$ the maximum body width; ${ }^{\mathrm{b}}$ the width in the level of ventral sucker; clength of the body and maximum body width ratio; ${ }^{\mathrm{d}}$ ventral and oral suckers length ratio; eventral and oral suckers width ratio. $\mathrm{BR}=\mathrm{Brazil} ; \mathrm{UK}=$ United Kingdom; $\mathrm{CR}=$ Czech Republic; $\mathrm{N}=$ number of measurements; $\mathrm{SD}=$ standard deviation; $\mathrm{B}=$ body; OS = oral sucker; VS = ventral sucker.

was subterminal (Figures $2 \mathrm{~A}, 2 \mathrm{~B}$, and $2 \mathrm{E}$ ) or terminal in a few worms, opening into the barrel-shaped pharynx (Figure 2E). The caeca were at the fourth to fifth part of the body, and the excretory vesicle extended in the posterior end. The vitelline glands were in follicles located laterally to the caeca (extracaecal) and were distributed from the distal pharynx region to the proximal ventral sucker area (four-fifths of the body) (Figure 2A). The lobed ovary was located anterolaterally to the ventral sucker, and the two lobed testes were placed on both sides of the ventral sucker (Figures 2H and 2I). The genital pore (Figures 2B, 2C, and 2H) was located at the median line, approximately $103 \mu \mathrm{m}$ down from the ventral sucker, and between these structures, the transverse vitelline ducts were observed (Figure $2 \mathrm{H}$ ). The parasites presented a long, coiled uterus with a large uterine sac with both immature (light brown shell) and mature (dark brown shell) operculate eggs (Figure 2G).

In a specimen without eggs (an immature adult worm) it was possible to verify a transversal connection in the $y$-shaped excretory vesicle, immediately after the ventral sucker (Figure 2I). The intestinal caeca divided immediately behind the pharynx, so it lacks an esophagus (Figure 2E).

The SEM of adults confirmed their roughly oval body shape (Figure 2B), the subterminal position of the oral sucker (Figure 2B), the genital pore lying at the median line of the ventral sucker (Figures 2B and 2C) and the well-developed cuticular spines covering the entire parasite body (Figure $2 \mathrm{C}$ ). The SEM also revealed the ultrastructural aspects of the egg shell, which is characterized by a dense network of irregular striated anastomosing ridges, covering the whole surface of the operculated barrel-shaped egg (Figure 2D).

\section{Molecular identification and phylogenetic analysis}

The amplicons of ITS2 region from the digeneans of the two $P$. puffinus exhibited the expected size (300 bp) and were sequenced (accession numbers: MH021181 and MH021182). The sequences from the digeneans of $P$. puffinus in this study showed $100 \%$ of nt similarity to each other and $95.9 \%, 96.6 \%$, and $87.3 \%$ with Renicola sloanei (accession number: KU563710; HENEBERG et al., 2016), Cercaria pythionike (accession number: DQ489707), and C. doricha (accession number: DQ489708) strains, respectively. The $C$. pythionike strain also exhibited a close molecular similarity with $R$. sloanei (96.2\%) (accession number: KU563710; HENEBERG et al., 2016). When compared with other species of the genus Renicola ( $R$. lari, $R$. pinguins, and $R$. sternae; HENEBERG et al., 2016) available in GenBank, the two nt sequences of $R$. sloanei of $P$. puffinus exhibited lower nt similarity $(68.6 \%, 74.2 \%$, and $68.8 \%$, respectively).

The amplified products of CO1 and ND1 loci had 463 and $434 \mathrm{bp}$, respectively. The sequence of $\mathrm{CO} 1$ locus from our renicolid (accession number: MK463857) also showed higher nt similarity with $R$. sloanei (90.6\%; accession number: KU563728) and lower nt similarity with $R$. pinguins $(82.1 \%$; accession number: 

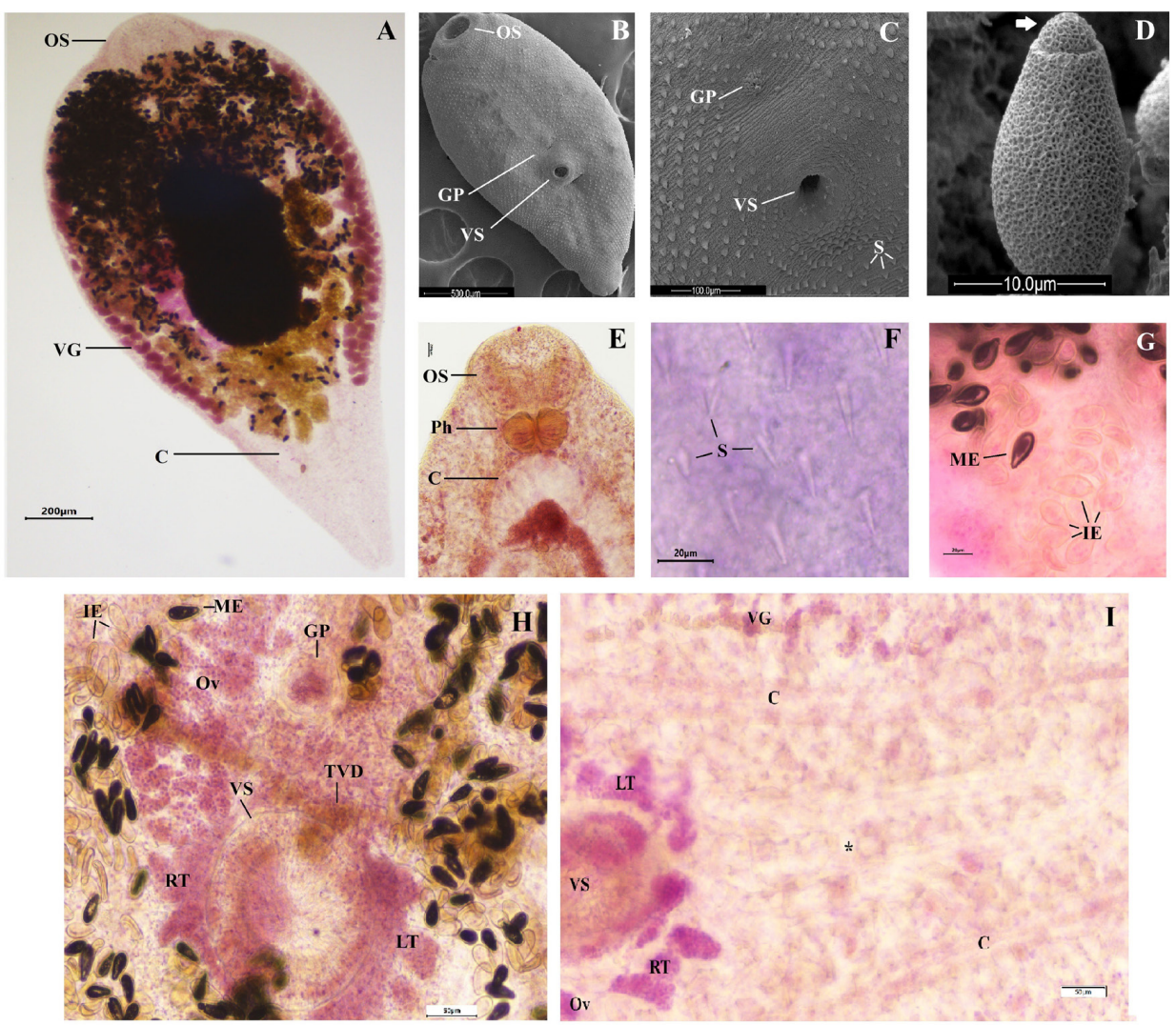

Figure 2. Histological stained with Mayer's carmalum (A, E, G, H, I) and Delafield's hematoxylin (E), and scanning electron microscopy (B, C, D) aspects of Renicola sloanei from Puffinus puffinus stranded on the coast of Paraná state, Brazil. (A) Body ovate (ventral aspect) (Bar $200 \mu \mathrm{m}$ ); (B) Scanning electron microscopy showing a roughly oval body (Bar $500 \mu \mathrm{m}$ ); (C) Scanning electron microscopy showing the spines and genital pore in the median line of the ventral sucker $($ Bar $100 \mu \mathrm{m})$; (D) Scanning electron microscopy of an egg with opercula (arrow) $($ Bar $10 \mu \mathrm{m})$; (E) The oral sucker subterminal opens into the pharynx barrel-shape and the caeca (Bar $200 \mu \mathrm{m})$; (F) Spines in the posterior end of the body (Bar $20 \mu \mathrm{m})$; (G) Mature eggs with miracidium and immature eggs in the uterus (Bar $200 \mu \mathrm{m})$; (H) Genital pore, transverse vitelline ducts, ovary lobed on the right side of the body, right and left testes lie on the side of the ventral sucker, observed in a helminth with few eggs (Bar $50 \mu \mathrm{m}$ ); (I) Ventral sucker, ovary, right and left testes, vitelline glands, ceacas and a connecting channel between the two arms of the excretory vesicle $\left(^{*}\right)$ in an immature adult helminth $($ Bar $50 \mu \mathrm{m})$. C = caeca; GP = genital pore; IE = immature eggs; $\mathrm{LT}=$ left teste; $\mathrm{ME}=$ mature eggs; $\mathrm{OS}=$ oral sucker; $\mathrm{Ov}=$ ovary; $\mathrm{Ph}=$ pharynx; $\mathrm{RT}=$ right teste; $\mathrm{S}=$ spines; TVD = transverse vitelline ducts; $\mathrm{VG}=$ vitelline glands; VS = ventral sucker.

KU563724), R. lari (80\%; accession numbers: KU563725, KU563726, KU563727), and R. sternae (79.2\%; accession numbers: KU563722, KU563723). Lower nt similarity was observed between our sequence and ND1 locus (accession number: MK463858) from others renicolids: $R$. pinguins $(77.5 \%$; accession number: KU563696), R. sternae (74.6\%; accession numbers: KU563693, KU563694, KU563695), and R. lari (72\%; accession number: KU563697). However, it was not possible to compare with the deposited sequence of $R$. sloanei from $S$. demersus (accession number: KU563692) due to the small sequence size (182 bp). Due to nt similarity (100\%) between the two P. puffinus strains in the ITS2 region, only one sequence with better nt quality of each locus (ND1 and CO1) was deposited in the GenBank database.

In the phylogenetic trees (Figure 3) the P. puffinus strains from this study clustered with $R$. sloanei strain, revealed by the analyses of ITS2 and CO1 loci (Figure 3A and 3B). In ND1 locus, the $P$. puffinus strain formed a separated branch from the other renicolids species (Figure 3C). In addition, in the ITS2 phylogenetic tree the $R$. sloanei strain clustered with $C$. pythionike and $C$. doricha (Figure 3A) strains.

\section{Discussion}

The parasitic infections generally cause low mortality and morbidity; there is also evidence that parasites can regulate the host population. However, the effects and the role of the parasites in the mortalities in marine birds are few understood (JONES, 2005; EBERT et al., 2000). In this way, the primary necessity is to identify the parasitic species and follow its biological cycle to better understand the relationship between parasitism and the host's health status. In this study, the results of the morphometrical and molecular assays were indicative of kidney parasitism by Renicola sloanei in Puffinus puffinus. 

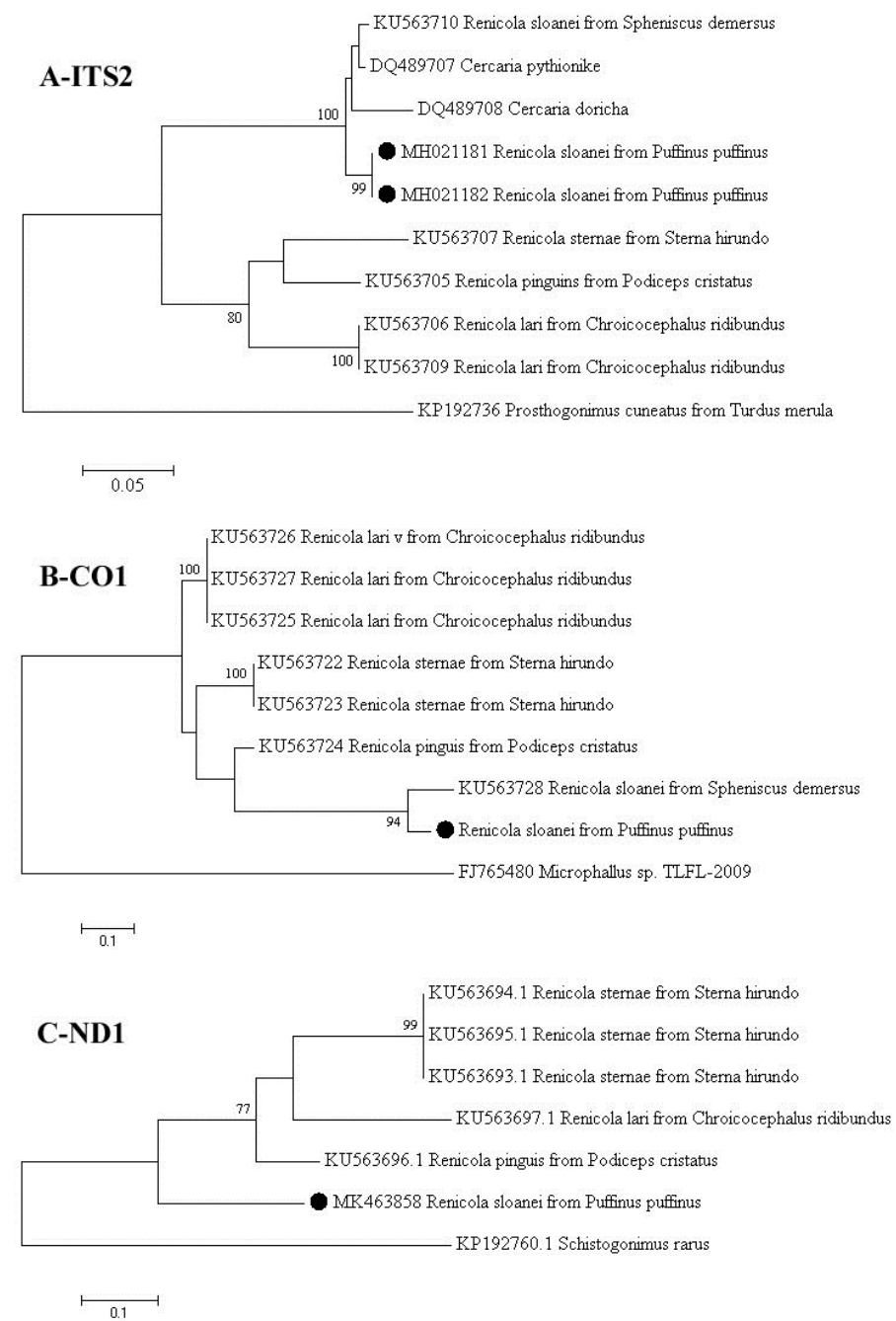

Figure 3. Phylogenetic analysis of the Renicola sloanei Brazilian field strains based on the ITS2 (3A), CO1 (3B), and ND1 (3C) regions. The trees were constructed using the Maximum Likelihood method with Kimura-two parameter model + invariant sites (K2+I) to ITS2 and Hasegawa-Kishino-Yano model + gama distribution $(\mathrm{HKY}+\mathrm{G})$ to $\mathrm{CO} 1$ and ND1. The bootstrap values are shown at the branch nodes (values $<60 \%$ are not shown). The scale bar at the bottom of the trees represent the number of nt substitutions per site. The sequences from this study are marked with filled circle and the GenBank accession numbers of the strains were provided. The Prosthogonimus cuneatus, Microphallus sp. and Schistogonimus rarus strains were used as outgroups.

There are few studies describing renal parasitic species in P. puffinus, possibly due to the difficulty in obtaining suitable specimens for more accurate identification (i.e., parasites with few eggs or that did not break during processing). The natural fragility of these worms and their arrangement in pairs inside the cysts made it very difficult to work with them without rupturing their bodies, either during removal from the cysts or during the staining procedures and slide assembly.

In a previous study of P. puffinus from the United Kingdom, a high rate of infection was also reported (number minimum of 30 and the maximum was not informed) (WRIGHT, 1956). The association between the histological lesions and the presence of Renicola spp. is controversial. A previous study of seabirds reported kidney lesions such as increased diameter of the renal tubules and inflammatory infiltrates that might result in death or contribute to the host's susceptibility to lethal infections (WRIGHT, 1956).
Conversely, R. sloanei from Spheniscus demersus (Linnaeus, 1758) on the coast of South Africa caused only mild tissue changes in histopathologic evaluation (HORNE et al., 2011). In the present study, the birds showed mild lesions in the kidneys. Apparently, the presence of parasites did not induce an inflammatory response or growth disorder in this host species, however, more studies should be performed to confirm this theory.

Two renicolids species were previously reported in P. puffinus, differentiated primarily by the extension of the vitelline glands (WRIGHT, 1956). In this report, the general morphology of the parasites showed similarity with $R$. sloanei recovered from penguins (WRIGHT, 1954a). At that time, the parasitism by R. sloane $i$ was identified only in penguin species (Aptenodytes patagonicus Miller, 1778, Pygoscelis antarcticus (Foster, 1781), Eudyptes chrysolophus (Brandt, 1837) and S. demersus) (CAMPBELL \& SLOAN, 1943; WRIGHT, 1954a; HORNE et al., 2011; HENEBERG et al., 
2016), and in Uria aalge (Pontoppidan, 1763) (WRIGHT, 1954a; COLE, 1959). In the present study, the morphological characteristics of the vitelline glands, caeca, and size of the eggs were similar to that reported for $R$. sloanei (Table 2).

The main characteristic that distinguished $R$. sloanei from other described renicolids was the different distribution of the vitelline glands (extra-caecal follicles extending from the second-fifth to the fourth-fifth body length) (WRIGHT, 1954a). The distribution of the vitelline glands were similar to Renicola spp. from Fratercula arctica (Linnaeus, 1758) and Colymbus arcticus (Linnaeus, 1758) (WRIGHT, 1956). In these last seabirds species, the renicolids were not identified at the species level; however, the author suggested that probably it were $R$. sloanei. In addition, the connection between the arms of the excretory vesicle was only observed in Renicola sp. from P. puffinus, R. sloanei from penguins and $U$. aalge, in Renicola spp. from $F$. arctica and C. arcticus and in Renicola glacialis Riley \& Owen, 1972 from Fulmarus glacialis (Linnaeus, 1761) (WRIGHT, 1954a, 1956; RILEY \& OWEN, 1972; KHAROO, 2013).

The length of the body of the renicolids derived from this study was similar to $R$. sloanei. Additionally, the ratios tend to present less variability those absolute measurements (FERNÁNDEZ et al., 1995); therefore, when suckers' length and width ratios of $R$. lari were compared with our results, a clear difference between the ratios were observed in these structures.

In the present study, the eggs' size showed dimensions similar to $R$. sloanei, Renicola sp. from S. magellanicus previously described (WRIGHT, 1954a; JERDY et al., 2016) (Table 2). It is also important to note that eggs from $R$. sloanei present smaller dimensions than $R$. lari from C. ridibundus and Renicola sp. from L. dominicanus (WRIGHT, 1954b; HENEBERG et al., 2016) (Table 2). The dimensions of the eggs differ between the renicolids species (WRIGHT, 1956). In this way, the size of the eggs is an useful parameter for the species differentiation, besides being a parameter of easy observation and measurement.

In this study, SEM was also used to characterize the parasites. A cuticle replete of spines and a well-developed genital pore were observed, which are characteristics not easily observed by histology. This last characteristic also was verified in R. sloanei (WRIGHT, 1954a). The similarity of the spines in the SEM and histologic slides indicate the preservation of this structure (Figures $2 \mathrm{C}$ and $2 \mathrm{~F}$ ). Furthermore, for the first time, the ultrastructural aspects of the eggs were shown, providing evidence of the opercule and the anastomosing ridges of the shell (Figure 2D).

Renicola sloanei probably is not species-specific but may be found in different definitive and intermediate hosts, and inhabiting various environments. Considering these biological aspects and the difficulty in obtaining adequate parasites for morphological analysis, molecular assays are essential for parasitic identification.

Phylogenetic analysis enabled us to classify the renicolids found in this study as $R$. sloanei. In the ITS2 region, the high nt similarity among $R$. sloanei strains from $P$. puffinus of this study $(100 \%)$ may be due to the parasitism of the same species as the definitive host. In addition, the strains presented less nt similarity
(95.9\%) with the other $R$. sloanei strains described previously by Heneberg et al. (2016) in S. demersus.

According to the morphological findings described by Wright (1956) and the phylogenetic analysis performed in this study, it can be suggested that $C$. pythionike is a metacercariae of $R$. sloanei, since it has the close nt similarity with $R$. sloanei of $P$. puffinus (96.6\%) (described herein) and with $R$. sloanei of S. demersus (96.2\%) (HENEBERG et al., 2016). In addition, C. pythionike, when compared to other renicolid strains, showed a reduced nt similarity with $R$. sternae $(69.2 \%)$, $R$. lari (68.4\%), and $R$. pinguins (74.6\%). However, to confirm this suggestion, additional morphological and molecular studies are required for Cercaria spp. and $R$. sloanei.

The sequences from both mitochondrial (CO1 and ND1) genes were used for comparison with sequences obtained using ribosomal DNA (ITS2) gene (MORGAN \& BLAIR, 1995), and due to the presence of greater nt variability are used to detect differences among the taxa (VILAS et al., 2005). Therefore, considering the variability of mitochondrial regions, the higher nt similarity between our digeneans and $R$. sloanei (CO1), and lower nt similarity with others renicolids (ND1 and CO1), we identified the renicolids from $P$. puffinus stranded on the coast of Paraná state as $R$. sloanei.

\section{Conclusions}

To the best of our knowledge, this is the first study using morphological and molecular assays to characterize the renal trematode $R$. sloane $i$ in P. puffinus. In addition, our results suggest that $R$. sloanei is the adult form of $C$. pythionike. However, additional investigations with these digeneans are required to confirm this information and to better evaluation of the renal lesions in parasitized $P$. puffinus on the Brazilian coast.

\section{Acknowledgements}

This study was prepared as part of the results obtained by the Beach Monitoring Project of the Santos Basin, state of Paraná, which is a requirement established by the federal environmental licensing division of the Brazilian Environmental Agency (IBAMA). This work has been made possible by the dedication of the collaborators of this project to obtain information and samples, and is part of the author's dissertation Matos, AMRN.

\section{References}

Amato JFR, Amato SB. Técnicas gerais para coleta e preparação de helmintos endoparasitos de aves. In: Von Matter S, Straube FC, Piacentini VQ, Accordi IA, Cândido JF Jr, editors. Ornitologia e conservação: ciência aplicada, técnicas de pesquisa e levantamento. Rio de Janeiro: Technical Books; 2010. p. 367-393.

Bowles J, Blair D, McManus DP. Genetic variants within the genus Echinococcus identified by mitochondrial DNA sequencing. Mol Biochem Parasitol 1992; 54(2): 165-173. http://dx.doi.org/10.1016/01666851(92)90109-W. PMid:1435857. 
Bray RA, Littlewood DTJ, Herniou EA, Williams B, Henderson RE. Digenean parasites of deep-sea teleosts: a review and case studies of intrageneric phylogenies. Parasitology 1999;119(1 Suppl): 125-144. http://dx.doi.org/10.1017/S0031182000084687. PMid:11254145.

Campbell JG, Sloan J. A possible new species of trematode parasite in the kidneys of the king penguin (Aptenodytes longirostris). Vet J 1943; 99(11): 291-294. http://dx.doi.org/10.1016/S0372-5545(17)33054-7.

Cole B. A report on the endoparasites found on Lundy, 1956-57. Annu Rep Lundy Field Soc 1959; 12: 31-34.

Ebert D, Lipsitch M, Mangin KL. The effect of parasites on host population density and extinction: experimental epidemiology with Daphnia and six microparasites. Am Nat 2000; 156(5): 459-477. http:// dx.doi.org/10.1086/303404. PMid:29587512.

Empresa Brasileira de Pesquisa Agropecuária - EMBRAPA. Electropherogram quality analysis [online]. 2019 [cited 2019 Jan 22]. Avaliable from: http:// asparagin.cenargen.embrapa.br/phph

Fernández M, Balbuena JA, Pertusa JF, Raga JA. Biometric variability of Hadwenius tursionis (Marchi, 1873) (Digenea, Campulidae) from the intestine of the bottlenose dolphin Tursiops truncatus (Montagu, 1821). Syst Parasitol 1995; 30(1): 67-76. http://dx.doi.org/10.1007/BF00009246.

Gibson DI. Family Renicolidae Dollfus, 1939. In: Gibson DI, Jones A, Bray RA, editors. Keys to Trematoda 3. London: CABI Publishing, The Natural History Museum; 2008. p. 591-594. (vol. 1). http://dx.doi. org/10.1079/9780851995885.0591.

Heneberg P, Sitko J, Bizos J, Horne EC. Central European parasitic flatworms of the family Renicolidae Dollfus, 1939 (Trematoda: Plagiorchiida): molecular and comparative morphological analysis rejects the synonymization of Renicola pinguis complex suggested by Odening. Parasitology 2016; 143(12): 1592-1604. http://dx.doi.org/10.1017/ S0031182016000895. PMid:27356772.

Horne EC, Bray RA, Bousfield B. The presence of the trematodes Cardiocephaloides physalis and Renicola sloanei in the African Penguin Spheniscus demersus on the east coast of South Africa. Ostrich 2011; 82(2): 157-160. http://dx.doi.org/10.2989/00306525.2011.603484.

Jerdy H, Baldassin P, Werneck MR, Bianchi M, Ribeiro RB, Carvalho ECQ. First report of kidney lesions due to Renicola sp. (Digenea: Trematoda) in free-living Magellanic Penguins (Spheniscus magellanicus Forster, 1781) found on the coast of Brazil. J Parasitol 2016; 102(6): 650-652. http:// dx.doi.org/10.1645/16-29. PMid:27552082.

Jones B. Mass mortalities in the oceans. In: Rohde K. Marine parasitology. Australia: CSIRO; 2005. p. 371-426.

Kharoo VK. A review of the history and classification of the family Renicolidae Dollfus, 1939 (Trematoda: Digenea). Ind J Fund Appl Life Sci 2013; 3(2): 6-12.

Kumar S, Stecher G, Tamura K. MEGA7: molecular evolutionary genetics analysis version 7.0 for bigger datasets. Mol Biol Evol 2016; 33(7): 18701874. http://dx.doi.org/10.1093/molbev/msw054. PMid:27004904.

MacKenzie K, Campbell N, Mattiucci S, Ramos P, Pinto AL, Abaunza P. Parasites as biological tags for stock identification of Atlantic horse mackerel Trachurus trachurus L. Fish Res 2008; 89(2): 136-145. http:// dx.doi.org/10.1016/j.fishres.2007.09.031.

Melo CMF, Oliveira JB, Athayde AC, Dantas AF, Feitosa TF, Vilela VL, et al. Identification of parasites in Puffinus puffinus (Birds, Procellariiformes) from Northeastern Brazil. Vet Res Commun 2012; 36(4): 235-238. http:// dx.doi.org/10.1007/s11259-012-9530-1. PMid:22833284.

Miura O, Kuris AM, Torchin ME, Hechinger RF, Dunham EJ, Chiba $S$. Molecular-genetic analyses reveal cryptic species of trematodes in the intertidal gastropod, Batillaria cumingi (Crosse). Int J Parasitol 2005; 35(7): 793-801. http://dx.doi.org/10.1016/j.ijpara.2005.02.014. PMid:15925598.

Morgan JAT, Blair D. Nuclear rDNA ITS sequence variation in the trematode genus Echinostoma: an aid to establishing relationships within the 37-collar-spine group. Parasitology 1995; 111(5): 609-615. http:// dx.doi.org/10.1017/S003118200007709X. PMid:8559594.

Morgan JAT, Blair D. Relative merits of nuclear ribosomal internal transcribed spacers and mitochondrial CO1 and ND1 genes for distinguishing among Echinostoma species (Trematoda). Parasitology 1998; 116(3): 289-297. http://dx.doi.org/10.1017/S0031182097002217. PMid:9550222.

National Center for Biotechnology Information - NCBI. Basic Local Alignment Search Tool - BLAST [online]. Bethesda; 2019 [cited 2019 Jan 22]. Avaliable from: https://blast.ncbi.nlm.nih.gov/Blast.cgi

Riley J, Owen RW. Renicola glacialis sp. nov., a new trematode from the north sea fulmar, Fulmarus glacialis (L.), with observations on its pathology. J Helminthol 1972; 46(1): 63-72. http://dx.doi.org/10.1017/ S0022149X00022124. PMid:5038425.

Sick H. Ordem Procellariiformes. In: Sick H. Ornitologia brasileira. Rio de Janeiro: Nova Fronteira; 1997. p. 175-185.

Stacy BA, Frankovich T, Greiner E, Alleman AR, Herbst LH, Klein $P$, et al. Detection of spirorchiid trematodes in gastropod tissues by polymerase chain reaction: preliminary identification of an intermediate host of Learedius learedi. J Parasitol 2010; 96(4): 752-757. http://dx.doi. org/10.1645/GE-2382.1. PMid:20496958.

Vilas R, Criscione CD, Blouin MS. A comparison between mitochondrial DNA and the ribosomal internal transcribed regions in prospecting for cryptic species of platyhelminth parasites. Parasitology 2005; 131(6): 839846. http://dx.doi.org/10.1017/S0031182005008437. PMid:16336737.

WoRMS Editorial Board - WoRMS. World Register of Marine Species [online]. 2018 [cited 2018 July 8]. Available from: http://www.marinespecies.org.

Wright CA. Studies on the life-history and ecology of the trematode genus Renicola Cohn, 1904. Proc Zool Soc Lond 1956; 126(1): 1-50. http://dx.doi.org/10.1111/j.1096-3642.1956.tb00423.x.

Wright CA. Trematodes of the genus Renicola from birds in British zoos, with descriptions of two new species. Proc Zool Soc Lond 1954a; 124(1): 51-61. http://dx.doi.org/10.1111/j.1096-3642.1954.tb01477.x.

Wright CA. Trematodes of the genus "Renicola" from the kidneys of birds in Brazil. Rev Bras Biol 1954b; 14: 61-64. 


\section{Supplementary Material}

Supplementary material accompanies this paper.

Table S1. Alignment of trimmed ITS2 locus corresponding to nt 99-415 (317 nt) of Prosthogonimus cuneatus, accession number in GenBank: KP192736, which consisted of partial 5.8S rDNA, full-length ITS2 and partial 28S rDNA sequence.

Table S2. Alignment of trimmed CO1 locus corresponding to nt 37-412 (376 nt) of Microphallus sp., accession number in GenBank: FJ765480, which consisted of partial CO1 coding sequence.

Table S3. Alignment of ND1 locus corresponding to nt 21-363 (343 nt) of Schistogonimus rarus, accession number in GenBank: KP192760, which consisted of partial ND1 coding sequence.

Table S4. Maximum likelihood fits of 24 nucleotide substitution models for the ITS2 locus, with all sites used for the analyses, including the gaps. For each model was calculated the Bayesian information criterion, Akaike information criterion (corrected), and maximum likelihood values.

Table S5. Maximum Likelihood fits of 24 nucleotide substitution models for the CO1 locus, with all sites used for the analyses, including the gaps. For each model was calculated the Bayesian information criterion, Akaike information criterion (corrected), and maximum likelihood values.

Table S6. Maximum Likelihood fits of 24 nucleotide substitution models for the ND1 locus, with all sites used for the analyses, including the gaps. For each model was calculated the Bayesian information criterion, Akaike information criterion (corrected), and maximum likelihood values.

This material is available as part of the online article from http://www.scielo.br/rbpv. 